OPEN ACCESS

Edited by:

Wan-Uk Kim,

Catholic University of Korea

South Korea

Reviewed by:

Yeonseok Chung,

Seoul National University, South Korea

Jan Fric,

International Clinical Research Center

(FNUSA-ICRC), Czechia

*Correspondence: Je-Min Choi

jeminchoi@hanyang.ac.kr

${ }^{\dagger}$ These authors have contributed equally to this work

Specialty section:

This article was submitted to

Inflammation,

a section of the journal

Frontiers in Immunology

Received: 31 August 2018 Accepted: 08 November 2018 Published: 27 November 2018

Citation:

Lee J-U, Kim L-K and Choi J-M (2018) Revisiting the Concept of Targeting NFAT to Control T Cell Immunity and Autoimmune Diseases.

Front. Immunol. 9:2747.

doi: 10.3389/fimmu.2018.02747

\section{Revisiting the Concept of Targeting NFAT to Control T Cell Immunity and Autoimmune Diseases}

\author{
Jae-Ung Lee ${ }^{1,2 \dagger}$, Li-Kyung Kim ${ }^{1,2 \dagger}$ and Je-Min Choi ${ }^{1,2 *}$ \\ ${ }^{1}$ Department of Life Science, College of Natural Sciences, Hanyang University, Seoul, South Korea, ${ }^{2}$ Research Institute for \\ Natural Sciences, Hanyang University, Seoul, South Korea
}

The nuclear factor of activated T cells (NFAT) family of transcription factors, which includes NFAT1, NFAT2, and NFAT4, are well-known to play important roles in T cell activation. Most of NFAT proteins are controlled by calcium influx upon T cell receptor and costimulatory signaling results increase of IL-2 and IL-2 receptor. NFAT3 however is not shown to be expressed in T cells and NFAT5 has not much highlighted in T cell functions yet. Recent studies demonstrate that the NFAT family proteins involve in function of lineage-specific transcription factors during differentiation of $\mathrm{T}$ helper 1 (Th1), Th2, Th17, regulatory $T$ (Treg), and follicular helper T cells (Tfh). They have been studied to make physical interaction with the other transcription factors like GATA3 or Foxp3 and they also regulate Th cell signature gene expressions by direct binding on promotor region of target genes. From last decades, NFAT functions in T cells have been targeted to develop immune modulatory drugs for controlling $T$ cell immunity in autoimmune diseases like cyclosporine A, FK506, etc. Due to their undesirable side defects, only limited application is available in human diseases. This review focuses on the recent advances in development of NFAT targeting drug as well as our understanding of each NFAT family protein in T cell biology. We also discuss updated detail molecular mechanism of NFAT functions in T cells, which would lead us to suggest an idea for developing specific NFAT inhibitors as a therapeutic drug for autoimmune diseases.

Keywords: NFAT, T cell, autoimmune disease, immune modulatory drugs, NFAT5

\section{INTRODUCTION: CLASSICAL NFATS}

Nuclear factor of activated T cells (NFAT) is a family of transcription factors identified in activated T cells, which promote the expression of interleukin-2 (IL-2) and the IL-2 receptor (1-3). Ligation of the T cell receptor (TCR) with antigen: major histocompatibility complex class II (MHCII) mediates multiple signaling cascades, including phospholipase C (PLC)dependent pathways, which generates the secondary messengers inositol-1,4,5-triphosphate $\left(\mathrm{IP}_{3}\right)$ and diacylglycerol (DAG). $\mathrm{IP}_{3}$ binds to $\mathrm{IP}_{3}$ receptor in the endoplasmic reticulum (ER) and releases $\mathrm{Ca}^{2+}$ ions to the cytoplasm $(4,5)$. Calmodulin captures free $\mathrm{Ca}^{2+}$ ions and activates the serine/threonine phosphatase calcineurin. Calcineurin dephosphorylates multiple serine residues in NFATs, resulting in their translocation into the nucleus $(5,6)$. NFAT proteins differentially regulate the expression of genes related to $\mathrm{T}$ cell development, activation, and differentiation $(1,7-11)$. 
The NFAT family proteins share a conserved N-terminal NFAT-homology region (NHR) and REL-homology region (RHR). The NHR is moderately conserved among NFAT family members and contains several serine-rich regions (SRR) and a transactivation domain. The NFAT family consists of five proteins: NFAT1 (NFATc2 or NFATp), NFAT2 (NFATc1 or NFATc), NFAT3 (NFATc4), NFAT4 (NFATc3 or NFATx), and NFAT5 (TonEBP or OREBP) (Figure 1) (12). NFAT1 is constitutively expressed in normal human $\mathrm{T}$ cells, whereas NFAT2 is induced by activation (13). NFAT1 and NFAT2 are regulated by calcineurin, which dephosphorylates NFATs and promotes their nuclear translocation (12). NFAT3 is rarely expressed in $\mathrm{T}$ cells because of lower chromatin accessibility and enhancer activity of its promoter (14). NFAT4 is weakly expressed in unstimulated cells and its expression is not enhanced by activation (13). NFAT1 and NFAT2 are the most-studied NFAT family members because of their high expression level in T cells. NFAT1 and NFAT2 surpass the ability of NFAT4 to bind to their target cytokine promoters (15). NFAT5 is expressed by almost all cells and is activated in response to osmotic stress (16). Translocated NFAT proteins interact with different transcription factors (such as AP1, FOXP3, and BATF) (1, 1719). Depending on partner proteins, NFATs can either enhance immune responses or induce immune tolerance. AP1, the most widely known partner protein of NFATs, forms a complex with NFATs and induces various cytokines (such as IL-2, IL-4, and IFN- $\gamma$ ) and other T cell activation-induced proteins (7).

As NFATs are involved in diverse molecular interactions, they are tightly regulated by post-translational modifications in the normal state (12). Several kinases, including casein kinase 1 (CK1), glycogen synthase kinase 3 (GSK3), JUN N-terminal kinase (JNK), and p38, phosphorylate the serine-rich motifs located in the NHR domain of NFAT proteins and maintain them in inactive state (20-23). In addition to phosphorylation, NFAT can be regulated by protein acetylation, proteolytic cleavage, and SUMOylation by the small ubiquitin-like modifier (SUMO) (24-26).

Considering the important role of NFAT proteins in regulation of $\mathrm{T}$ cell activation, several therapeutic approaches were developed to inhibit NFAT signaling. Calcineurin inhibitors, such as cyclosporine A (CsA) and tacrolimus (FK506), have been used to treat graft rejection and autoimmune diseases, including atopic dermatitis, rheumatoid arthritis, and lupus nephritis (27-32). More inhibitors specifically targeting NFATs (such as VIVIT peptide, INCA-1, ST-1959, and UR-1505) were developed and are being verified; however, they are yet to be analyzed in suitable animal models of autoimmune diseases to investigate their potential of ameliorating diseases (33-36).

\section{NFAT IN T CELL SUBSETS: TH1, TH2, TH17, TREG, AND TFH}

Th1: Although NFAT was originally identified to play important roles in the activation of T cells, it has also been shown that NFAT proteins differentially affect $\mathrm{T}$ helper (Th) cell differentiation (Figure 2) (37-41). Each differentiated T subset is characterized by the expression of their specific master regulator transcription factors and signature cytokines. Th1 cells are essential effector T cells against intracellular bacteria and virus infections $(42,43)$. Th1 differentiation is induced by TCR signaling and priming cytokines such as IFN- $\gamma$ and IL-12 $(44,45)$. Together with antigen stimulation, cytokine-mediated signal transducer and activator of transcription 1 (STAT1) activates T-bet (TBX21), a master transcription factor of Th1 $(46,47)$. The expression of NFAT2a, an isotype of NFAT2, is more elevated in Th1 and Th2 than in Th17 and Treg (48). NFAT1 binds to IFN- $\gamma$ promoter region $(11,49)$. Loss of NFAT1 promotes mild bias toward Th2 cell differentiation with decreased production of IFN- $\gamma$ and increased production of IL-4 $(38,39,44,50-52)$. In double knock-out (DKO) mice, the levels of Th2-related cytokines such as IL-4 and IL-5 increased 25- to 75-fold compared to in wild type mice with increased IgG1 and IgE titers (39). Recent studies showed that $\mathrm{Ca}^{2+}$ response is more intense and sustained in Th1 and that NFAT nuclear localization is shorter in Th2 than in Th1 (53), suggesting that NFAT1 and/or NFAT4 are positive regulators of Th1 inflammation.

Th2: In contrast, Nfat2-deficient mice show impaired production of IL-4 and Th2 cytokines and reduced IgG1 and IgE levels (40). Th2 cells express IL-4, IL-5, and IL-13, which stimulates mucosal immunity against parasite infections (5456). Various transcription factors, namely, GATA3, STAT6, RBPJK, MAF, IRF4, and JUNB, have been implicated in Th2 differentiation and function (10, 57-61). GATA3 forms a chromatin hub with NFAT1 in Il4 and Il13 promoter regions (62). IRF4 synergizes with NFAT1 and c-Maf to augment Il4 promoter activity $(10,40)$. Ubiquitin-specific peptidase 4 (USP4) interacts with IRF4 and NFAT1 to enhance NFATmediated Il4 promoter activity (63). RUNX3 physically interacts with NFAT2 and suppresses IL-4 production (64). NFAT1 competitively binds to the CRTh2 promoter with GATA3 and negatively regulates CRTh2 expression, which mediates the production of Th2 cytokines such as IL-4, IL-5, and IL-13 (65). Nfat1 deficiency increased Th2 cytokine levels, enhanced chromatin accessibility, and increased DNA demethylation in the Il4 promoter region, inducing preferential recruitment of JUNB/SATB1 to the Il4 promoter $(51,52)$. Similarly, Nfat1/4 DKO CD4T cells secrete large amounts of IL-4 upon TCR stimulation, and show increased Th2 cytokine production, which is not dependent on IL-4 production (40). Early growth response protein-1 (EGR1) is expressed predominantly in Th2 and cooperatively binds to the Il4 enhancer element with NFAT1/2 (66). IL-31 cytokine induction in Th2 cells require $\mathrm{Ca}^{2+}$ mediated NFAT1/2 activation (67). NFAT2 and STAT6 synergistically enhance Il31 promoter activity. These studies suggest that NFAT2 plays positive regulatory roles in Th2 inflammation with possible reciprocal relationship with NFAT1 or NFAT4.

Th17: Th17 subsets are important players in protection against extracellular pathogens and inflammatory response in autoimmune diseases $(68,69)$. Signature cytokines including IL17A, IL-17F, IL-21, and IL-22 produced by Th17 cells induce massive tissue reaction such as neutrophil recruitment (70). NFAT is also important in the induction of these cytokines. NFAT1 and 2 directly bind to the $I l 17$ promoter region 


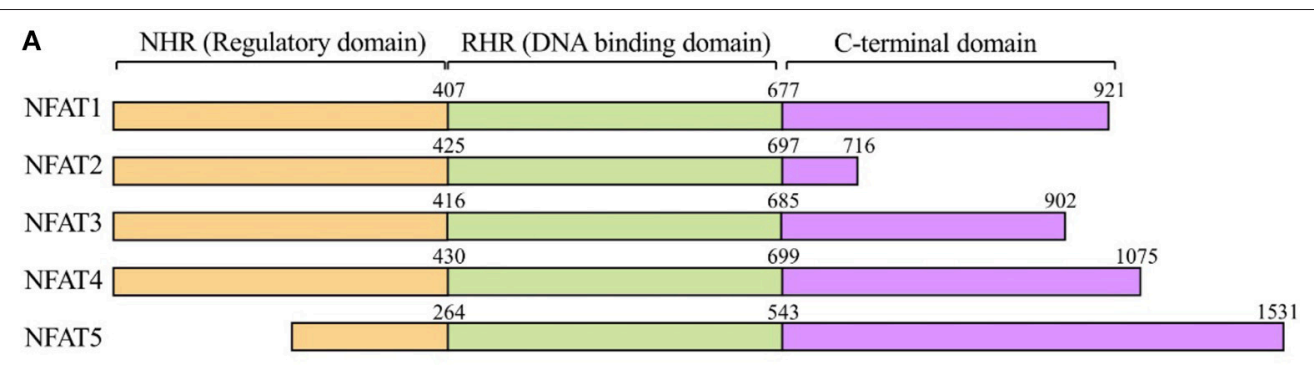

B

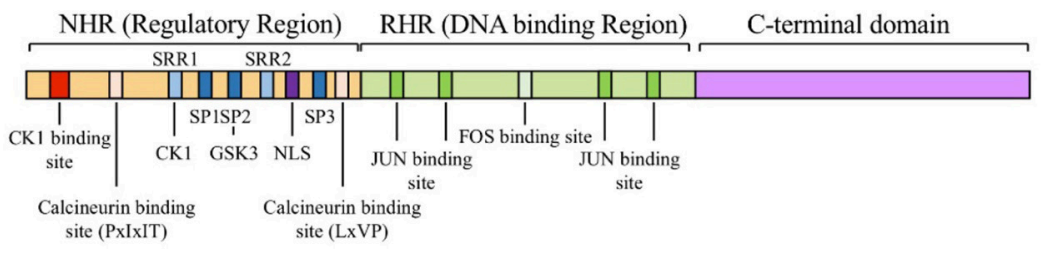

FIGURE 1 | The NFAT protein family and structure of NFATs. (A) General structure of nuclear factor of activated T-cells (NFAT) protein family. The NFAT family consists of five protein members: NFAT1 (NFATc2 or NFATp), NFAT2 (NFATc1 or NFATC), NFAT3 (NFATc4), NFAT4 (NFATc3 or NFATx), and NFAT5 (TonEBP or OREBP). NFAT proteins contain a REL homology region (RHR), NFAT homology region (NHR), and C-terminal domain. RHR, which binds to DNA, is the most conserved domain, and $\mathrm{NHR}$, the regulatory domain, is conserved from NFAT1 to NFAT4, but not in NFAT5. (B) Schematic alignment of NFAT proteins. NHR consists of several conserved regulatory motifs. The NHR contains casein kinase 1(CK1), GSK3 docking site, calcineurin docking site, and PxIxIT and LxVP motifs. NFAT5 lacks the NHR regulatory domain. NHR also contains a nuclear localization signal (NLS), which is required for nucleus translocation, serine-rich regions (SRRs), serine- proline-repeat motifs (SPs), and a phosphorylation site that is dephosphorylated by regulatory phosphatases such as calcineurin, CK1, and GSK3. RHR, the DNA binding domain, contains binding sites for FOS and JUN. NFAT5 lacks binding motifs for FOS and JUN.

(71-74). CD4-specific Nfat2-deficient mice showed reduced IL17 expression, and $N f a t 1$ and $N f a t 2$-deficient mice (DKO) showed reduction in IL-17 expression (75). In a model of experimental colitis, Nfat1 deficiency showed protective effects with reduced production of IL- 6 and IL-17 by mucosal T lymphocytes (76). Hyperactivation of NFAT1, increased affinity for calcineurin, and decreased affinity for CK1, resulted in higher IL-17 and IL-10 production because of direct binding of NFAT1 to distal regulatory regions of $I l 17$ and Il10 loci (73). Although NFAT1 hyperactivation induced production of IL-17 in vitro, mice were more resistant to induction of experimental autoimmune encephalomyelitis (EAE), with increased production of IL-10 and accumulation of Treg cells in the central nervous system. Conversely, CD4-specific Nfat2-deficient mice showed reduced levels of ROR $\gamma \mathrm{t}$, a master transcription regulator of Th17, as well as reduction in IL-17A, IL-17F, and IL-21 production and protected from EAE (77). Although Nfat1-deficient mice also showed decreased inflammatory response in the EAE model, the underlying mechanism is different from that in Nfat2deficient mice. CD4-specific Nfat1-deficient T cells secrete IL17 along with IL-4 and IL-10, and these non-pathogenic Th17 cells contribute to protection from diseases (78). The above observations suggest that both NFAT1 and NFAT2 contribute to Th17 response.

Treg: FOXP3 ${ }^{+}$Treg cells are a distinct population suppressing other effector Th cells (79) and is divided into thymus-derived natural FOXP3 ${ }^{+}$(nTreg) T cells and peripheral inducible Treg (iTreg) (80). Studies on Treg cells were facilitated by the identification of mutations in Foxp3 in mice and patients of immunodysregulation polyendocrinopathy enteropathy Xlinked (IPEX) syndrome (81-83). Treg-mediated immune suppression is caused by multiple mechanisms such as CTLA4-, IL-10-, TGF $\beta$-, and antigen presenting cell (APC)-mediated indirect inhibition (84-86). Most of these Treg-related molecules are regulated by NFAT proteins $(17,73,87)$. Ablation of Nfat1, Nfat2, and Nfat4 alone or in combination such as $N f a t 1 / 2$ and $N f a t 1 / 4$ double KO diminished iTreg but not nTreg differentiation, suggesting specific roles of the NFAT family in peripheral activation and differentiation of regulatory $\mathrm{T}$ cells from naïve $\mathrm{T}$ cells (75). Studies show that NFAT facilitates the interaction between conserved noncoding sequence 2 (CNS2) at the Foxp3 locus and Foxp3 promoter, and that NFAT2 directly regulates SMAD3 and FOXP3 binding to CNS1, enhancing production of effector molecules in Treg (88-91). Specific inhibition of NFAT1/FOXP3 interaction using a FOXP3-derived peptide, FOXP3 393-403, impaired Tregmediated suppressor function in a dose-dependent manner (92). This peptide also inhibited Treg differentiation in mice and human $\mathrm{T}$ cells and showed enhanced antitumor responses. However, several recent studies have reported that Nfat KO mice show increased GITR ${ }^{+}$Treg cells in the lung after allergen challenge and protection in graft-vs.-host diseases (GvHD) $(93,94)$. The functions of NFAT in Treg responses are still controversial and more accurate studies are required.

Tfh: Tfh cells were recently identified as helper $\mathrm{T}$ cells expressing transcription factor B-cell lymphoma 6 (BCL6) (95). Tfh cells are distinguished from other Th cells by their 


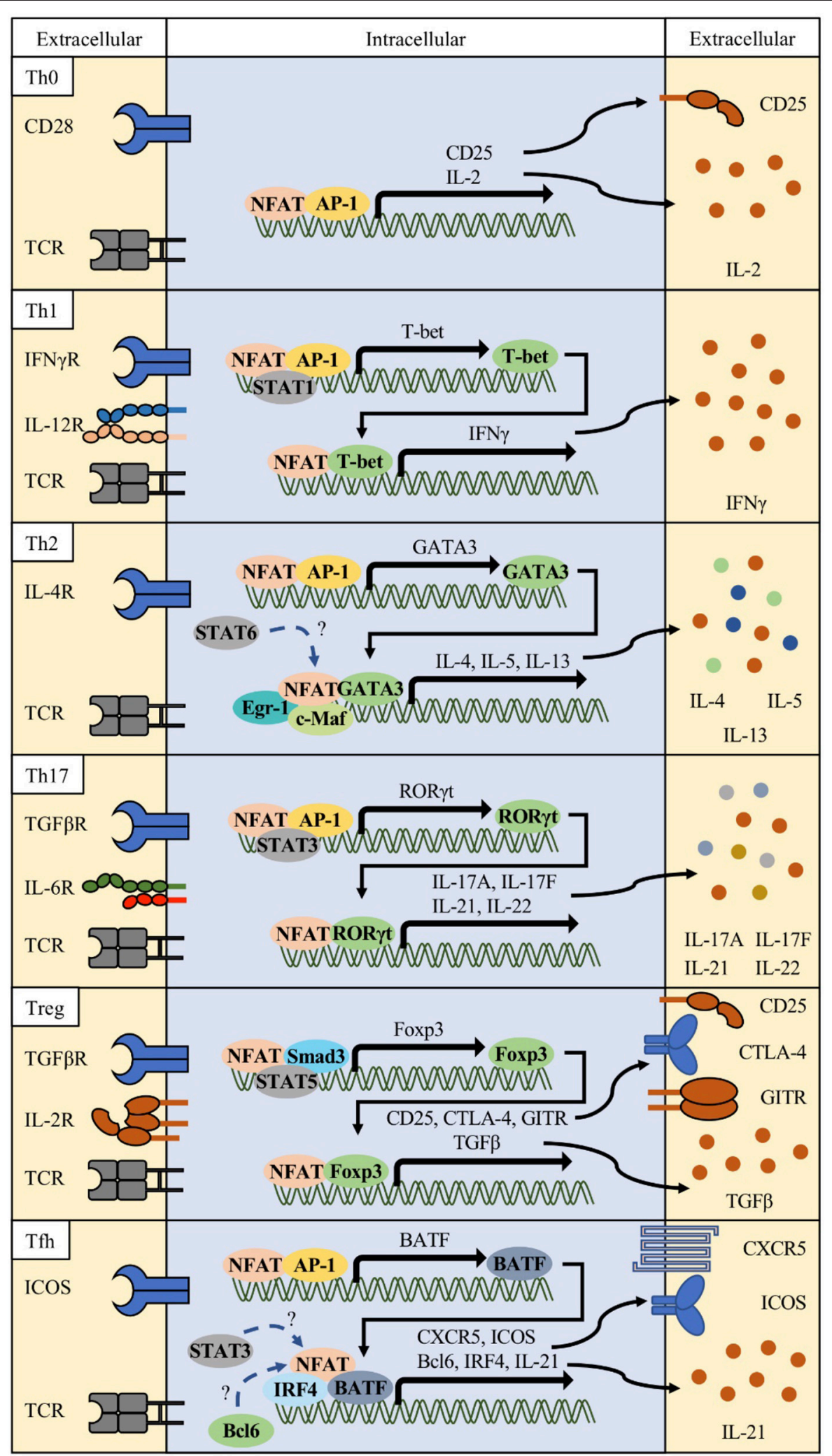

FIGURE 2 | Various combinations of NFAT and interacting partner proteins in T helper cells. Differentiation of each Th cell is initiated by activation of T cell receptor (TCR), costimulatory receptor signals (e.g., CD28 or ICOS), and specific lineage determining cytokine signals. These signals orchestrate to induce the NFAT/AP-1 complex to express lineage-related transcription factors such as T-bet for Th1, GATA3 for Th2, ROR $\gamma$ t for Th17, and BATF for follicular helper T (Tfh) cells. In combination with these transcription factors, NFAT/partner protein complexes determine their lineage differentiation and functional characteristics (surface receptors and cytokine production). 
selective role in inducing germinal center (GC) responses, with promotion of antibody class switching, somatic hypermutation, high affinity antibody production, and plasma cell differentiation (96). Tfh cells express the C-X-C motif chemokine receptor 5 (CXCR5) and localize into the GC of draining lymph nodes (97). In addition to BCL6, other transcription factors including STATs, MAF, BATF, IRF4, ASCL2, LEF-1, and TCF-1 are also essential for Tfh differentiation and function (98-103). Both Tfh and GC B cells express high levels of NFAT1 and NFAT2, which is indicative of the functional importance of NFAT family in humoral immunity $(104,105)$. Increased humoral responses were observed in Nfat1- and Nfat4-deficient mice with increased serum levels of IgG1 and IgM (39). In contrast, Nfat2-deficient T cells show reduced IgG1 and IgE levels (106). Thereafter, some studies reported that NFAT regulates the expression of molecules important for Tfh cell function and differentiation, such as interferon regulatory factor 4 (IRF4), programmed death-1 (PD-1), and CXCR5 (10, 104, 107). It is also known that NFAT is required for IL-21 production, which is important for Tfh differentiation and function, and its production was ablated by CsA treatment (108-110). However, IL-21 inhibits Tfr expansion via a BCL6-mediated mechanism (109). NFAT2 has especially high expression in human and mouse Tfh cells, and NFAT1 level increased slightly in mouse Tfh cells $\left(\mathrm{CD}^{+} \mathrm{ICOS}^{+} \mathrm{CXCR}^{+}\right)(104,111)$, although NFAT3 and NFAT4 expression was not induced. Nuclear level of NFAT2a, an isoform of autoregulated NFAT2, and Nfat2 P1 promoter activity increased in Tfh cells, which is suggestive of specific roles of NFAT2 in Tfh cells. T cell-specific Nfat2-deficient mice $\left(N f a t 2^{f l / f l} \times C d 4^{c r e}\right)$ showed increase in Tfh cell population and GC responses in mesenteric lymph nodes and elevation in 4hydroxy-3-nitrophenylacetyl (NP)-specific IgM, IgG1, and IgG3 levels after NP-conjugated keyhole limpet hemocyanin (KLH) immunization. We reasoned that the increase in Tfh population and GC responses in Nfat2-deficient mice was due to impaired expression of CXCR5 in follicular regulatory $\mathrm{T}$ cells (Tfr). In fact, Nfat2 deletion in Treg cells (Foxp3-IRES-Cre $\times$ Nfat $2^{f l / f l}$ ) reduced the Tfr population, and similar responses were observed with CD4-specific Nfat2-deficient mice upon immunization. However, in a model of lymphocytic choriomeningitis virus (LCMV) infection, Nfat1/2-deficient mice showed impaired Tfh differentiation with reduced production of LCMV-specific antibody and functional molecules such as PD-1, ICOS, Ly108, CXCR5, and SLAM (112). In this model system, adoptively transferred LCMV-specific CD4 T cells (SMARTA CD4 T cells) also showed decreased Tfh differentiation and GC responses. Abolished store-operated $\mathrm{Ca}^{2+}$ entry (SOCE), which is a driving mechanism of NFAT activation in T cells, exhibits spontaneous increase in GC B cells and humoral autoimmunity due to low Tfr induction, whereas LCMV infection reduced Tfh cell differentiation and LCMV-specific IgG titers, suggesting different roles of NFAT depending on specific antigenic stimulation and environment, including presence of other immune cell types (19). Thus, NFAT1 and NFAT2 appear to exert positive regulatory effects on Tfh differentiation or function, whereas NFAT3 and NFAT4 are not required for Tfh or humoral immunity.

\section{NFAT5 IN T CELLS}

NFAT5, also known as tonicity-responsive enhancer binding protein (TonEBP) or osmotic response element binding protein (OREBP), is the most recently identified member of the NFAT family (113-116). NFAT5 does not possess calcineurin binding domain, and is hence the only NFAT family protein that is not regulated by calcium signaling (117). In response to osmotic stress, NFAT5 is activated by p38/MAPK signaling and regulates the expression of osmoprotective genes required for normal function (118). Therefore, studies on NFAT5 initially focused primarily on kidney medulla, skin, and eyes exposed to hypertonicity (119). However, NFAT5 is expressed not only in these tissues but also in the thymus and activated $\mathrm{T}$ lymphocytes (16). NFAT5 binds to TNF- $\alpha$ and lymphotoxin $\beta$ promoter, suggesting that NFAT5 plays another role in the immune system, especially in T cells (120). Dominant negative (DN) Nfat5 transgenic mice presented impaired thymic development and reduced peripheral $\mathrm{T}$ cell numbers. In addition, transgenic $\mathrm{T}$ cells and Jurkat cell lines expressing DN Nfat5 also exhibited impaired proliferation and viability (121). Furthermore, Nfat5null mice had hypernatremia and $\mathrm{T}$ cell lymphopenia, whereas T cell-specific Nfat5 knockout mice had isotonic plasma and normal $\mathrm{T}$ cell numbers, but decreased survival and proliferation in hypertonic condition. These altered $\mathrm{T}$ cell homeostasis are associated with NFAT5-dependent CD24 induction in T cells (122). Other studies have shown that NFAT5 also has osmostressindependent functions. In the thymus, NFAT5 regulates the progression from double-negative stage and therefore controls survival during thymocyte development. Nfat5-deficient mice had smaller thymus and less mature CD4 and CD8 cells in the spleen and lymph nodes (123). Recent studies showed that high salt conditions promote the differentiation of naïve $\mathrm{T}$ cells into Th17 cells via NFAT5-dependent mechanisms with more pathogenic characteristics and GM-CSF production. Short hairpin RNA (shRNA)-mediated silencing of Nfat5 in CD4 T cells decreased IL-17A and CCR6 expression in Th17 polarizing conditions, suggesting a new role in the pathogenesis of autoimmune diseases involving NFAT5 activation $(124,125)$. High-salt diet increases the number of Th17 cells in vivo and aggravates EAE via the NFAT5/SGK1 pathway (125). Under hypertonic conditions, NFAT5 enhances the expression of the pathogenic Th17-related cytokine IL-17A and Th17-assosiated genes, Rorc and Il23r, in T cells. In contrast, in vivo-activated $N$ fat-deficient CD4 T cells were skewed toward increased IFN $\gamma$ and IL-17A expression, and T cell-restricted Nfat5-deficient mice exhibited more severe pathology and enhanced IFN $\gamma$ mRNA expression in lymph nodes and colon of an animal model of experimental colitis (126). Recent studies identified that several miRNAs can target Nfat5. miR-20b was studied in thymoma-associated myasthenia gravis, where it inhibited NFAT5 expression with reduced $\mathrm{T}$ cell proliferation (127). miR-568 expression decreased during Treg activation and correlated inversely with NFAT5 expression. Overexpression of miR-568 inhibited Treg differentiation and TGF $\beta$ and IL-10 production (128). Another study showed that the expression of the microRNA cluster 106a 363 decreased during Th17 cell 
differentiation and that over-expression of miR-18b, miR-106a, and miR-363-3p reduced Th17 differentiation (129). These effects of the miRNA 106a 363 cluster are mediated by inhibition of their targets such as Nfat5 and Rorc. Patients with inflammatory bowel disease (IBD), including those with Crohn's disease (CD), ulcerative colitis (UC), and autoimmune enteropathy (AIE), have significantly reduced NFAT5 expression (130). NFAT5 inhibition in healthy human and murine $\mathrm{T}$ cells exhibited disruption in cytokine production and survival (130).

We have briefly summarized the role of each NFAT family proteins in T cell immunity (Table 1). These observations suggest that NFAT5 plays an important role in $\mathrm{T}$ cells under both hypertonic and isotonic conditions and in Treg function. NFAT5 may be a new attractive target for the treatment of autoimmune diseases irrespective of calcium-mediated adverse effects.

\section{NFAT TARGETING DRUGS FOR AUTOIMMUNITY: BEYOND CYCLOSPORINE A AND TACROLIMUS}

Considering the important role of NFAT signaling in $\mathrm{T}$ cell function, NFAT has long been considered as an attractive target for therapeutic approaches to control autoimmune responses and graft rejection (Table 2) $(30,31,163,164)$. The most wellknown drugs targeting NFAT are the calcineurin inhibitors CsA and FK506. CsA was first identified in 1971 from the fungus Tolypocladium inflatum $(165,166)$. Later, tacrolimus, also known as FK506, was isolated from a fungus named Streptomyces tsukubaensis (167). CsA and FK506 function similarly in that they bind to immunophilins called cyclophilin and FKbinding protein 12 (FKBP12), respectively (168-170). This inhibitor-immunophilin complex directly binds to calcineurin and inhibits its phosphatase activity, thereby inhibiting NFAT dephosphorylation (171). Both drugs have been well-used to treat graft rejection and autoimmune diseases. CsA and tacrolimus are used in atopic dermatitis and in other autoimmune diseases, including lupus nephritis, and many clinical trials have been conducted to determine the efficacy of calcineurin inhibitors
(30-32). In fact, calcineurin inhibitors positively affect the treatment of autoimmune membranous nephropathy $(172,173)$. Similarly, recent studies revealed that CsA inhibits Th17 cells in patients with Sjögren's syndrome and rheumatoid arthritis $(174,175)$. Treatment of rheumatoid arthritis with tacrolimus and other drugs such as methotrexate showed promising synergy in clinical results $(27,176)$. Although calcineurin inhibitors are effective in autoimmune disease therapy with inhibition of $\mathrm{T}$ cell activation, inhibition of calcineurin has serious drawbacks; for example, blocking of calcineurin phosphatase activity affects numerous targets of calcineurin as well as NFATs. Neurotoxicity and nephrotoxicity are the most common side effects of calcineurin inhibitors $(177,178)$. Calcineurin is also highly expressed in neural tissues (179). It regulates $\mathrm{IP}_{3}$ and the ryanodine receptor and thereby controls calcium flux in the cerebellum (180). It is also associated with gamma aminobutyric acid $\left(\mathrm{GABA}_{\mathrm{A}}\right)$ and $\mathrm{N}$-methyl $\mathrm{D}$-aspartate (NMDA) receptors $(181,182)$. Calcineurin also plays an important role in exocytosis and vesicle recycling of neurotransmitters and nitric oxide synthase (NOS) (183-185). Nephrotoxicity of calcineurin inhibitors is associated with TGF $\beta$ and endothelin production. TGF $\beta$ increases the extracellular matrix (ECM) by inducing collagen and fibronectin, resulting in tubular fibrosis and anti-TGF $\beta$ antibody-neutralized nephrotoxic effects $(186,187)$. Endothelin level is also increased by calcineurin inhibitors. Endothelin is related to endothelial dysfunction, impaired glomerular filtration, and systemic hypertension (188, 189). Recent studies have indicated that calcineurin inhibitors have a negative effect on regulatory $\mathrm{T}$ cell proliferation and function, which are necessary for immune tolerance $(190,191)$. Hence, investigations for identifying more selective and less toxic inhibitors without affecting calcineurin activity are underway.

To identify alternative NFAT inhibitors, a VIVIT peptide derived from the calcineurin-NFAT binding motif, PxIxIT, was developed to block NFAT binding to calcineurin and NFAT-dependent gene expression without affecting calcineurin phosphatase activity $(143,144)$. To resolve the delivery limitation of the VIVIT peptide, several studies modified VIVIT peptides using cell penetrating peptides (CPPs). 11R-conjugated VIVIT

TABLE 1 | NFAT family in T cell immunity.

\begin{tabular}{|c|c|c|c|}
\hline Regulation & NFAT family member & Expression in the immune system & Functions in T cell immunity \\
\hline \multirow[t]{4}{*}{$\begin{array}{l}\mathrm{Ca}^{2+/} \\
\text { Calcineurin }\end{array}$} & NFAT1 & Expressed in all types of Th cells & $\begin{array}{l}\text { Positive regulator of Th1 inflammation. } \\
\text { Positively regulate Th17-cytokines, IL-17, and IL-6. } \\
\text { Interacts with FOXP3 and enhances effector molecules in Treg. }\end{array}$ \\
\hline & NFAT2 & Expressed in all types of Th cells & $\begin{array}{l}\text { Positive regulatory role in Th2 responses } \\
\text { Stimulates ROR } \gamma T \text { and Th17-realted cytokines } \\
\text { Positively regulates Treg differentiation with NFAT1/4 } \\
\text { Enhances Tfh differentiation and function }\end{array}$ \\
\hline & NFAT3 & Rarely expressed in T cells & Unknown \\
\hline & NFAT4 & $\begin{array}{l}\text { Expressed in thymocytes and weakly } \\
\text { expressed in peripheral T cells }\end{array}$ & $\begin{array}{l}\text { Thymocyte development and survival } \\
\text { TCR hyper-reactivity } \\
\text { Positive synergy with NFAT1 in Th1 and Treg response }\end{array}$ \\
\hline Osmotic stress & NFAT5 & Expressed in thymocytes and iTreg & $\begin{array}{l}\text { Thymocyte development and survival } \\
\text { Hypersensitivity in hypertonic condition } \\
\text { Th17-mediated disease pathogenicity }\end{array}$ \\
\hline
\end{tabular}


TABLE 2 | Calcineurin-NFAT inhibitors and their mechanisms.



successfully increased transplant survival in islet transplanted mice (145). Other studies showed that Sim-2-conjugated VIVIT was efficiently delivered into cells and inhibited IL-2 and alleviated ovalbumin (OVA)-induced asthma in a murine model (192). In addition, the C-terminus of the regulatory domain possesses a conserved calcineurin binding motif, LxVP, which facilitates calcineurin docking and NFAT dephosphorylation (193, 194). However, LxVP presented weak binding strength for NFAT1 and affected calcineurin phosphatase activity (146, 195). Endogenous calcineurin inhibitors such as AKAP79, 
Cabin-1/Cain, MCIP1, and A238L have sequences similar to that of the PxIxIT motif (147, 148, 196-198).

Small molecules are similar in structure and function to classical inhibitors but have lesser side effects. Voclosporin (ISA247), an analog of CsA, possesses higher affinity to cyclophilin than CsA and was effective at lower concentrations (137). Therefore, it is considered a promising treatment option for arthritis and psoriasis $(199,200)$. Other drugs such as ST-1959, and Roc-1, 2, and 3 inhibit $\mathrm{T}$ cell responses by enhancing nuclear export of NFAT1 and NFAT2 $(35,152)$. Drugs such as zoledronic acid induce NFAT1 degradation via GSK3 $\beta$ inhibition (153). Certain inhibitors such as UR-1505 and digitoxin block the binding of NFAT to DNA (155). Remarkably, digitoxin specifically inhibits interaction between NFAT1 and the c-Myc promoter and thereby inhibits c-Mycdependent transcription (162). The FOXP3-derived peptide, FOXP3 393-403, specifically inhibits FOXP3/NFAT interaction. This inhibitory peptide suppresses $\mathrm{T}$ cell conversion into iTregs and enhances $\mathrm{T}$ cell proliferation, thereby exhibiting antitumor effects (92). These strategies indicated that blockage of NFAT binding to a specific promoter or inhibition of its interaction to a particular transcriptional partner might selectively suppress its function.

To develop these NFAT inhibitory molecules as a new drug for human diseases, both $\mathrm{T}$ cells and other cells also should be considered for therapeutic purposes. Recent studies in myeloid cells have revealed the importance of NFAT in both innate and adaptive immunity. In an early response to pathogens, pattern recognition receptors (PRRs) such as TLR4 and dectin1 induce the production of IL-2 from dendritic cells $(201,202)$. These signals activate PLC $\gamma 2$ and promote NFAT-dependent IL2 expression. In macrophages that express various NFAT family members except NFAT3, calcineurin/NFAT inhibitor treatment results in macrophages that are tolerant to lethal dose of lipopolysaccharide (LPS) (203-205). Other myeloid cells such as mast cells and neutrophils are influenced by $\mathrm{Ca}^{2+} / \mathrm{NFAT}$ signaling and produce cytokines and multiple immune mediators $(206,207)$. Therefore, NFAT targeting strategies should consider non-T cell mediated adverse effects as well as its potent effect of disease control and immune suppression.

Considering the multiple roles of calcineurin-NFAT signaling in both immune and non-immune cells, new methods for targeting NFAT are required. For peptide inhibitors such as VIVIT and LxVP, improved CPPs such as dNP2 can be used to enhance efficiency of in vivo delivery (208). Alternatively, more specific inhibition strategies other than calcineurin targeting can be used. Recent results regarding the role of each NFAT family member in $\mathrm{T}$ cells and the molecular mechanisms via which they regulate $\mathrm{T}$ cell responses indicate that new inhibitors that

\section{REFERENCES}

1. Shaw JP, Utz PJ, Durand DB, Toole JJ, Emmel EA, Crabtree GR. Identification of a putative regulator of early T cell activation genes. Science (1988) 241:2025. doi: $10.1126 /$ science. 3260404 can block specific molecular interactions should be developed to reduce side effects and reinforce the efficacy of autoimmune disease therapy.

\section{CONCLUDING REMARKS AND PERSPECTIVES}

In the current review, we have summarized recent advances in our understanding of the role of NFAT family members in $\mathrm{T}$ cell responses and presented an overview of therapeutic agents targeting NFAT proteins for treating autoimmune diseases. Classically, NFAT has been studied as an important transcription factor for $\mathrm{T}$ cell activation under calcium signaling. However, recent studies revealed that NFAT function is not just limited to $\mathrm{T}$ cell activation but it also actively functions in differentiation of effector T cell subsets such as Th1, Th2, Th17, Treg, and Tfh cells. Based on better understanding of molecular mechanism of NFAT by direct interaction with T-bet, GATA3, ROR $\gamma \mathrm{t}$, FOXP3, and BCL6, or by promoter binding to control T cell differentiationrelated genes, we now are able to suggest a strategy to develop specific NFAT inhibitor to control a particular function of NFATs. Unlike other calcineurin-dependent NFAT proteins, NFAT5 in $\mathrm{T}$ cells is just recently recognized that it seems to be involved in thymocyte development and T cell survival and proliferation. Interestingly, it could be activated under high salt condition in $\mathrm{T}$ cells to commit more pathogenic Th17 differentiation in multiple sclerosis model. While it is still questionable whether specific NFAT5 inhibition in $\mathrm{T}$ cells would be beneficial for autoimmunity, it could be worth to investigate as a new target of NFAT inhibition for treating autoimmune diseases. As previously developed NFAT targeting drugs show significant adverse effects owing to the diverse calcium signaling-related target genes of NFAT proteins, a novel strategy either targeting specific NFAT family members or molecular interference of NFAT binding proteins will be more beneficial for controlling $\mathrm{T}$ cell function and autoimmune diseases.

\section{AUTHOR CONTRIBUTIONS}

All authors listed have made a substantial, direct and intellectual contribution to the work, and approved it for publication.

\section{ACKNOWLEDGMENTS}

This work was supported by the Bio \& Medical Technology Development Program (NRF-2017M3A9C8027972) and Basic Science Research Program (NRF-2016R1E1A1A01941034) of the National Research Foundation of Korea.

2. Chen L, Rao A, Harrison SC. Signal integration by transcription-factor assemblies: interactions of NF-AT1 and AP-1 on the IL-2 promoter. Cold Spring Harb Symp Quant Biol. (1999) 64:527-31. doi: 10.1101/sqb.1999. 64.527 
3. Henderson DJ, Naya I, Bundick RV, Smith GM, Schmidt JA. Comparison of the effects of FK-506, cyclosporin A and rapamycin on IL-2 production. Immunology (1991) 73:316-21.

4. Hogan PG, Lewis RS, Rao A. Molecular basis of calcium signaling in lymphocytes: STIM and ORAI. Annu Rev Immunol. (2010) 28:491-533. doi: 10.1146/annurev.immunol.021908.132550

5. Feske S. Calcium signalling in lymphocyte activation and disease. Nat Rev Immunol. (2007) 7:690-702. doi: 10.1038/nri2152

6. Hogan PG, Chen L, Nardone J, Rao A. Transcriptional regulation by calcium, calcineurin, and NFAT. Genes Dev. (2003) 17:2205-32. doi: $10.1101 / \operatorname{gad} .1102703$

7. Macián F, López-Rodríguez C, Rao A. Partners in transcription: NFAT and AP-1. Oncogene (2001) 20:2476-89. doi: 10.1038/sj.onc.1204386

8. Jain J, McCaffrey PG, Valge-Archer VE, Rao A. Nuclear factor of activated T cells contains Fos and Jun. Nature (1992) 356:801-4. doi: 10.1038/356801a0

9. Avni O, Lee D, Macian F, Szabo SJ, Glimcher LH, Rao A. T(H) cell differentiation is accompanied by dynamic changes in histone acetylation of cytokine genes. Nat Immunol. (2002) 3:643-51. doi: 10.1038/ni808

10. Rengarajan J, Mowen KA, McBride KD, Smith ED, Singh H, Glimcher LH. Interferon regulatory factor 4 (IRF4) interacts with NFATc2 to modulate interleukin 4 gene expression. J Exp Med. (2002) 195:1003-12. doi: 10.1084/jem.20011128

11. Lee DU, Avni O, Chen L, Rao A. A distal enhancer in the interferon-gamma (IFN-gamma) locus revealed by genome sequence comparison. J Biol Chem. (2004) 279:4802-10. doi: 10.1074/jbc.M307904200

12. Macian F. NFAT proteins: key regulators of T-cell development and function. Nat Rev Immunol. (2005) 5:472-84. doi: 10.1038/nri1632

13. Lyakh L, Ghosh P, Rice NR. Expression of NFAT-family proteins in normal human T cells. Mol Cell Biol. (1997) 17:2475-84. doi: 10.1128/MCB.17.5.2475

14. Kaminuma O, Kitamura N, Nishito Y, Nemoto S, Tatsumi H, Mori A, et al. Downregulation of NFAT3 Due to Lack of T-Box Transcription Factor TBX5 Is Crucial for Cytokine Expression in T Cells. J Immunol. (2018) 200:92-100. doi: 10.4049/jimmunol.1602113

15. Timmerman LA, Healy JI, Ho SN, Chen L, Goodnow CC, Crabtree GR. Redundant expression but selective utilization of nuclear factor of activated T cells family members. J Immunol. (1997) 159:2735-40.

16. Trama J, Lu Q, Hawley RG, Ho SN. The NFAT-related protein NFATL1 (TonEBP/NFAT5) is induced upon $\mathrm{T}$ cell activation in a calcineurin-dependent manner. J Immunol. (2000) 165:4884-94. doi: 10.4049/jimmunol.165.9.4884

17. Wu Y, Borde M, Heissmeyer V, Feuerer M, Lapan AD, Stroud JC, et al. FOXP3 controls regulatory $\mathrm{T}$ cell function through cooperation with NFAT. Cell (2006) 126:375-87. doi: 10.1016/j.cell.2006.05.042

18. Bettelli E, Dastrange M, Oukka M. Foxp3 interacts with nuclear factor of activated $\mathrm{T}$ cells and NF-kappa $\mathrm{B}$ to repress cytokine gene expression and effector functions of T helper cells. Proc Natl Acad Sci USA. (2005) 102:5138-43. doi: 10.1073/pnas.0501675102

19. Vaeth M, Eckstein M, Shaw PJ, Kozhaya L, Yang J, Berberich-Siebelt $\mathrm{F}$, et al. Store-Operated $\mathrm{Ca}(2+)$ Entry in Follicular $\mathrm{T}$ cells controls humoral immune responses and autoimmunity. Immunity (2016) 44:135064. doi: 10.1016/j.immuni.2016.04.013

20. Beals CR, Sheridan CM, Turck CW, Gardner P, Crabtree GR. Nuclear export of NF-ATc enhanced by glycogen synthase kinase-3. Science (1997) 275:1930-4. doi: 10.1126/science.275.5308.1930

21. Chow CW, Rincón M, Cavanagh J, Dickens M, Davis RJ. Nuclear accumulation of NFAT4 opposed by the JNK signal transduction pathway. Science (1997) 278:1638-41.

22. Okamura H, Garcia-Rodriguez C, Martinson H, Qin J, Virshup DM, Rao A. A conserved docking motif for CK1 binding controls the nuclear localization of NFAT1. Mol Cell Biol (2004) 24:4184-95. doi: 10.1128/MCB.24.10.4184-4195.2004

23. Yang TT, Xiong Q, Enslen H, Davis RJ, Chow CW. Phosphorylation of NFATc4 by p38 mitogen-activated protein kinases. Mol Cell Biol (2002) 22:3892-904. doi: 10.1128/MCB.22.11.3892-3904.2002

24. Kim JH, Kim K, Youn BU, Jin HM, Kim JY, Moon JB, et al. RANKL induces NFATc1 acetylation and stability via histone acetyltransferases during osteoclast differentiation. Biochem J. (2011) 436:253-62. doi: $10.1042 / \mathrm{BJ} 20110062$
25. Wu W, Misra RS, Russell JQ, Flavell RA, Rincón M, Budd RC. Proteolytic regulation of nuclear factor of activated T (NFAT) c2 cells and NFAT activity by caspase-3. J Biol Chem. (2006) 281:10682-90. doi: 10.1074/jbc.M511759200

26. Nayak A, Glöckner-Pagel J, Vaeth M, Schumann JE, Buttmann M, Bopp T, et al. Sumoylation of the transcription factor NFATc1 leads to its subnuclear relocalization and interleukin-2 repression by histone deacetylase. J Biol Chem. (2009) 284:10935-46. doi: 10.1074/jbc.M9004 65200

27. Takahashi N, Fujibayashi T, Kida D, Hirano $\mathrm{Y}$, Kato T, Kato D, et al. Concomitant methotrexate and tacrolimus augment the clinical response to abatacept in patients with rheumatoid arthritis with a prior history of biological DMARD use. Rheumatol Int. (2015) 35:1707-16. doi: 10.1007/s00296-015-3283-4

28. Yeh H, Markmann JF. Transplantation: Are calcineurin inhibitors safer than mTOR inhibitors? Nat Rev Nephrol. (2013) 9:11-3. doi: 10.1038/nrneph.2012.262

29. Hirai T, Ikeda K, Fujishiro M, Tsushima H, Hayakawa K, Suzuki S, et al. The effectiveness of new triple combination therapy using synthetic disease-modifying anti-rheumatic drugs with different pharmacological function against rheumatoid arthritis: the verification by an in vitro and clinical study. Clin Rheumatol. (2017) 36:51-58. doi: 10.1007/s10067-0163458-8

30. Mok CC. Calcineurin inhibitors in systemic lupus erythematosus. Best Pract Res Clin Rheumatol. (2017) 31:429-38. doi: 10.1016/j.berh.2017. 09.010

31. Wells G, Haguenauer D, Shea B, Suarez-Almazor ME, Welch VA, Tugwell P, et al. Cyclosporine for rheumatoid arthritis. Cochrane Database Syst Rev. (2000) 2000:CD00(1083). doi: 10.1002/14651858.CD001083

32. Hanifin JM, Ling MR, Langley R, Breneman D, Rafal E. Tacrolimus ointment for the treatment of atopic dermatitis in adult patients: part I, efficacy. J Am Acad Dermatol. (2001) 44(1 Suppl.):S28-38. doi: 10.1067/mjd.2001.109810

33. Yu H, van Berkel TJ, Biessen EA. Therapeutic potential of VIVIT, a selective peptide inhibitor of nuclear factor of activated $\mathrm{T}$ cells, in cardiovascular disorders. Cardiovasc Drug Rev (2007) 25:175-87. doi: 10.1111/j.1527-3466.2007.00011.x

34. Roehrl MH, Kang S, Aramburu J, Wagner G, Rao A, Hogan PG. Selective inhibition of calcineurin-NFAT signaling by blocking protein-protein interaction with small organic molecules. Proc Natl Acad Sci USA. (2004) 101:7554-9. doi: 10.1073/pnas.0401835101

35. Lindstedt R, Ruggiero V, D' Alessio V, Manganello S, Petronzelli F, Stasi MA, et al. The immunosuppressor st1959, a 3,5-diaryls-triazole derivative, inhibits $\mathrm{T}$ cell activation by reducing NFAT nuclear residency. Int J Immunopathol Pharmacol. (2009) 22:29-42. doi: 10.1177/039463200902200105

36. Bailón E, Román J, Ramis I, Michelena P, Balsa D, Merlos M, et al. The new salicylate derivative UR-1505 modulates the Th2/humoral response in a dextran sodium sulphate model of colitis that resembles ulcerative colitis. $J$ Pharmacol Sci. (2009) 109:315-8. doi: 10.1254/jphs.08292SC

37. Hodge MR, Ranger AM, Charles de la Brousse F, Hoey T, Grusby MJ, Glimcher LH. Hyperproliferation and dysregulation of IL-4 expression in NF-ATp-deficient mice. Immunity (1996) 4:397-405. doi: 10.1016/S1074-7613(00)80253-8

38. Kiani A, Viola JP, Lichtman AH, Rao A. Down-regulation of IL-4 gene transcription and control of Th2 cell differentiation by a mechanism involving NFAT1. Immunity (1997) 7:849-60.

39. Ranger AM, Oukka M, Rengarajan J, Glimcher LH. Inhibitory function of two NFAT family members in lymphoid homeostasis and Th2 development. Immunity (1998) 9:627-35. doi: 10.1016/S1074-7613(00)80660-3

40. Rengarajan J, Tang B, Glimcher LH. NFATc2 and NFATc3 regulate $\mathrm{T}(\mathrm{H}) 2$ differentiation and modulate TCR-responsiveness of naive $\mathrm{T}(\mathrm{H})$ cells. Nat Immunol. (2002) 3:48-54. doi: 10.1038/ni744

41. Bopp T, Palmetshofer A, Serfling E, Heib V, Schmitt S, Richter C, et al. NFATc2 and NFATc3 transcription factors play a crucial role in suppression of CD4+ T lymphocytes by CD4+ CD25+ regulatory T cells. J Exp Med. (2005) 201:181-7. doi: 10.1084/jem.20041538

42. Khader SA, Cooper AM. IL-23 and IL-17 in tuberculosis. Cytokine (2008) 41:79-83. doi: 10.1016/j.cyto.2007.11.022 
43. Ramshaw IA, Ramsay AJ, Karupiah G, Rolph MS, Mahalingam S, Ruby JC. Cytokines and immunity to viral infections. Immunol Rev. (1997) 159:11935. doi: 10.1111/j.1600-065X.1997.tb01011.x

44. Kiani A, García-Cózar FJ, Habermann I, Laforsch S, Aebischer T, Ehninger $\mathrm{G}$, et al. Regulation of interferon-gamma gene expression by nuclear factor of activated T cells. Blood (2001) 98:1480-8. doi: 10.1182/blood.V98.5.1480

45. Schoenborn JR, Wilson CB. Regulation of interferon-gamma during innate and adaptive immune responses. Adv Immunol. (2007) 96:41-101. doi: 10.1016/S0065-2776(07)96002-2

46. Szabo SJ, Sullivan BM, Stemmann C, Satoskar AR, Sleckman BP, Glimcher LH. Distinct effects of T-bet in TH1 lineage commitment and IFNgamma production in CD4 and CD8 T cells. Science (2002) 295:338-42. doi: 10.1126/science. 1065543

47. Afkarian M, Sedy JR, Yang J, Jacobson NG, Cereb N, Yang SY, et al. T-bet is a STAT1-induced regulator of IL-12R expression in naive CD4+ T cells. Nat Immunol. (2002) 3:549-57. doi: 10.1038/ni794

48. Hock M, Vaeth M, Rudolf R, Patra AK, Pham DA, Muhammad K, et al. NFATc1 induction in peripheral T and B lymphocytes. J Immunol. (2013) 190:2345-53. doi: 10.4049/jimmunol.1201591

49. Agarwal S, Avni O, Rao A. Cell-type-restricted binding of the transcription factor NFAT to a distal IL-4 enhancer in vivo. Immunity (2000) 12:643-52. doi: 10.1016/S1074-7613(00)80215-0

50. Erb KJ, Twardzik T, Palmetshofer A, Wohlleben G, Tatsch U, Serfling E. Mice deficient in nuclear factor of activated T-cell transcription factor c2 mount increased Th2 responses after infection with Nippostrongylus brasiliensis and decreased Th1 responses after mycobacterial infection. Infect Immun. (2003) 71:6641-7. doi: 10.1128/IAI.71.11.6641-6647.2003

51. Fonseca BP, Olsen PC, Coelho LP, Ferreira TP, Souza HS, Martins MA, et al. NFAT1 transcription factor regulates pulmonary allergic inflammation and airway responsiveness. Am J Respir Cell Mol Biol. (2009) 40:66-75. doi: 10.1165/rcmb.2007-0102OC

52. Son JS, Chae CS, Hwang JS, Park ZY, Im SH. Enhanced chromatin accessibility and recruitment of JUNB mediate the sustained IL-4 expression in NFAT1 deficient $\mathrm{T}$ helper 2 cells. PLoS ONE (2011) 6:e22042. doi: 10.1371/journal.pone.0022042

53. Izsepi E, Himer L, Szilagyi O, Hajdu P, Panyi G, Laszlo G, et al. Membrane microdomain organization, calcium signal, and NFAT activation as an important axis in polarized Th cell function. Cytometry A (2013) 83:185-96. doi: 10.1002/cyto.a.22234

54. Tepper RI, Levinson DA, Stanger BZ, Campos-Torres J, Abbas AK, Leder P. IL-4 induces allergic-like inflammatory disease and alters $\mathrm{T}$ cell development in transgenic mice. Cell (1990) 62:457-67. doi: 10.1016/0092-8674(90)90011-3

55. Ricci M, Matucci A, Rossi O. IL-4 as a key factor influencing the development of allergen-specific Th2-like cells in atopic individuals. J Investig Allergol Clin Immunol (1997) 7:144-50.

56. Perrigoue JG, Zaph C, Guild K, Du Y, Artis D. IL-31-IL-31R interactions limit the magnitude of Th2 cytokine-dependent immunity and inflammation following intestinal helminth infection. J Immunol. (2009) 182:6088-94. doi: 10.4049/jimmunol.0802459

57. Agarwal S, Rao A. Modulation of chromatin structure regulates cytokine gene expression during T cell differentiation. Immunity (1998) 9:765-75.

58. Amsen D, Blander JM, Lee GR, Tanigaki K, Honjo T, Flavell RA. Instruction of distinct $\mathrm{CD} 4 \mathrm{~T}$ helper cell fates by different notch ligands on antigen-presenting cells. Cell (2004) 117:515-26. doi: 10.1016/s0092-8674(04)00451-9

59. Zheng W, Flavell RA. The transcription factor GATA-3 is necessary and sufficient for Th2 cytokine gene expression in CD4 T cells. Cell (1997) 89:587-96.

60. Li B, Tournier C, Davis RJ, Flavell RA. Regulation of IL-4 expression by the transcription factor JunB during T helper cell differentiation. EMBO J. (1999) 18:420-32.

61. Lohoff M, Mittrücker HW, Prechtl S, Bischof S, Sommer F, Kock $\mathrm{S}$, et al. Dysregulated $\mathrm{T}$ helper cell differentiation in the absence of interferon regulatory factor 4. Proc Natl Acad Sci USA. (2002) 99:11808-12. doi: 10.1073/pnas.182425099

62. Yao X, Zha W, Song W, He H, Huang M, Jazrawi E, et al. Coordinated regulation of IL-4 and IL-13 expression in human T cells: $3 \mathrm{C}$ analysis for DNA looping. Biochem Biophys Res Commun. (2012) 417:996-1001. doi: 10.1016/j.bbrc.2011.12.069

63. Guo Z, Xu P, Ge S, Zhang C, Zheng X, Xu J, et al. Ubiquitin specific peptidase 4 stabilizes interferon regulatory factor protein and promotes its function to facilitate interleukin-4 expression in T helper type 2 cells. Int J Mol Med. (2017) 40:979-86. doi: 10.3892/ijmm.2017.3087

64. Lee SH, Jeong HM, Choi JM, Cho YC, Kim TS, Lee KY, et al. Runx3 inhibits IL-4 production in T cells via physical interaction with NFAT. Biochem Biophys Res Commun. (2009) 381:214-7. doi: 10.1016/j.bbrc.2009. 02.026

65. MacLean Scott E, Solomon LA, Davidson C, Storie J, Palikhe NS, Cameron L. Activation of Th2 cells downregulates CRTh2 through an NFAT1 mediated mechanism. PLoS ONE (2018) 13:e199156. doi: 10.1371/journal.pone.0199156

66. Lohoff M, Giaisi M, Köhler R, Casper B, Krammer PH, Li-Weber M. Early growth response protein-1 (Egr-1) is preferentially expressed in $\mathrm{T}$ helper type 2 (Th2) cells and is involved in acute transcription of the Th2 cytokine interleukin-4. J Biol Chem. (2010) 285:1643-52. doi: 10.1074/jbc.M109.011585

67. Park K, Park JH, Yang WJ, Lee JJ, Song MJ, Kim HP. Transcriptional activation of the IL31 gene by NFAT and STAT6. J Leukoc Biol. (2012) 91:245-57. doi: 10.1189/jlb.0111020

68. Korn T, Bettelli E, Oukka M, Kuchroo VK. IL-17 and Th17 Cells. Annu Rev Immunol. (2009) 27:485-517. doi: 10.1146/annurev.immunol.021908.132710

69. Ghoreschi K, Laurence A, Yang XP, Tato CM, McGeachy MJ, Konkel JE, et al. Generation of pathogenic $\mathrm{T}(\mathrm{H}) 17$ cells in the absence of TGF-beta signalling. Nature (2010) 467:967-71. doi: 10.1038/nature09447

70. Kolls JK, Lindén A. Interleukin-17 family members and inflammation. Immunity (2004) 21:467-76. doi: 10.1016/j.immuni.2004.08.018

71. Gomez-Rodriguez J, Sahu N, Handon R, Davidson TS, Anderson SM, Kirby $\mathrm{MR}$, et al. Differential expression of interleukin-17A and-17F is coupled to $\mathrm{T}$ cell receptor signaling via inducible T cell kinase. Immunity (2009) 31:587-97. doi: 10.1186/2050-6511-15-35

72. Hermann-Kleiter N, Meisel M, Fresser F, Thuille N, Müller M, Roth L, et al. Nuclear orphan receptor NR2F6 directly antagonizes NFAT and RORgammat binding to the Il17a promoter. J Autoimmun. (2012) 39:428-40. doi: 10.1016/j.jaut.2012.07.007

73. Ghosh S, Koralov SB, Stevanovic I, Sundrud MS, Sasaki Y, Rajewsky K, et al. Hyperactivation of nuclear factor of activated T cells 1 (NFAT1) in T cells attenuates severity of murine autoimmune encephalomyelitis. Proc Natl Acad Sci USA. (2010) 107:15169-74. doi: 10.1073/pnas.1009193107

74. Hermann-Kleiter N, Baier G. Orphan nuclear receptor NR2F6 acts as an essential gatekeeper of Th17 CD4+ T cell effector functions. Cell Commun Signal. (2014) 12:38. doi: 10.1186/1478-811X-12-38

75. Vaeth M, Schliesser U, Müller G, Reissig S, Satoh K, Tuettenberg A, et al. Dependence on nuclear factor of activated T-cells (NFAT) levels discriminates conventional T cells from Foxp3+ regulatory T cells. Proc Natl Acad Sci USA. (2012) 109:16258-63. doi: 10.1073/pnas.1203870109

76. Weigmann B, Lehr HA, Yancopoulos G, Valenzuela D, Murphy A, Stevens $\mathrm{S}$, et al. The transcription factor NFATc2 controls IL-6-dependent $\mathrm{T}$ cell activation in experimental colitis. J Exp Med. (2008) 205:2099-110. doi: 10.1084/jem.20072484

77. Reppert S, Zinser E, Holzinger C, Sandrock L, Koch S, Finotto $\mathrm{S}$. NFATc1 deficiency in $\mathrm{T}$ cells protects mice from experimental autoimmune encephalomyelitis. Eur J Immunol. (2015) 45:1426-40. doi: 10.1002/eji.201445150

78. Dietz L, Frommer F, Vogel AL, Vaeth M, Serfling E, Waisman A, et al. NFAT1 deficit and NFAT2 deficit attenuate EAE via different mechanisms. Eur J Immunol. (2015) 45:1377-89. doi: 10.1002/eji.201444638

79. Tang Q, Bluestone JA. The Foxp3+ regulatory T cell: a jack of all trades, master of regulation. Nat Immunol. (2008) 9:239-44. doi: 10.1038/ni1572

80. Sakaguchi S, Yamaguchi T, Nomura T, Ono M. Regulatory T cells and immune tolerance. Cell (2008) 133:775-87. doi: 10.1016/j.cell.2008.05.009

81. Brunkow ME, Jeffery EW, Hjerrild KA, Paeper B, Clark LB, Yasayko SA, et al. Disruption of a new forkhead/winged-helix protein, scurfin, results in the fatal lymphoproliferative disorder of the scurfy mouse. Nat Genet. (2001) 27:68-73. doi: $10.1038 / 83784$ 
82. Bennett CL, Christie J, Ramsdell F, Brunkow ME, Ferguson PJ, Whitesell $\mathrm{L}$, et al. The immune dysregulation, polyendocrinopathy, enteropathy, Xlinked syndrome (IPEX) is caused by mutations of FOXP3. Nat Genet. (2001) 27:20-1. doi: 10.1038/83713

83. Wildin RS, Ramsdell F, Peake J, Faravelli F, Casanova JL, Buist N, et al. X-linked neonatal diabetes mellitus, enteropathy and endocrinopathy syndrome is the human equivalent of mouse scurfy. Nat Genet. (2001) 27:18-20. doi: 10.1038/83707

84. Read S, Greenwald R, Izcue A, Robinson N, Mandelbrot D, Francisco $\mathrm{L}$, et al. Blockade of CTLA- 4 on $\mathrm{CD} 4+\mathrm{CD} 25+$ regulatory $\mathrm{T}$ cells abrogates their function in vivo. J Immunol. (2006) 177:4376-83. doi: 10.4049/jimmunol.177.7.4376

85. Rubtsov YP, Rasmussen JP, Chi EY, Fontenot J, Castelli L, $\mathrm{Ye} \mathrm{X}$, et al. Regulatory $\mathrm{T}$ cell-derived interleukin-10 limits inflammation at environmental interfaces. Immunity (2008) 28:546-58. doi: 10.1016/j.immuni.2008.02.017

86. Zheng SG, Wang JH, Gray JD, Soucier H, Horwitz DA. Natural and induced CD4+CD25+ cells educate CD4+CD25- cells to develop suppressive activity: the role of IL-2, TGF-beta, and IL-10. J Immunol. (2004) 172:521321. doi: 10.4049/jimmunol.172.9.5213

87. Singh G, Singh SK, König A, Reutlinger K, Nye MD, Adhikary T, et al. Sequential activation of NFAT and c-Myc transcription factors mediates the TGF-beta switch from a suppressor to a promoter of cancer cell proliferation. J Biol Chem. (2010) 285:27241-50. doi: 10.1074/jbc.M110.100438

88. Li Q, Shakya A, Guo X, Zhang H, Tantin D, Jensen PE, et al. Constitutive nuclear localization of NFAT in Foxp3+ regulatory $\mathrm{T}$ cells independent of calcineurin activity. J Immunol. (2012) 188:4268-77. doi: 10.4049/jimmunol.1102376

89. Li X, Liang Y, LeBlanc M, Benner C, Zheng Y. Function of a Foxp3 ciselement in protecting regulatory $\mathrm{T}$ cell identity. Cell (2014) 158:734-48. doi: 10.1016/j.cell.2014.07.030

90. Tone Y, Furuuchi K, Kojima Y, Tykocinski ML, Greene MI, Tone M. Smad3 and NFAT cooperate to induce Foxp3 expression through its enhancer. Nat Immunol. (2008) 9:194-202. doi: 10.1038/ni1549

91. Zhou M, Zou R, Gan H, Liang Z, Li F, Lin T, et al. The effect of aging on the frequency, phenotype and cytokine production of human blood CD4 + CXCR5 + T follicular helper cells: comparison of aged and young subjects. Immun Ageing (2014) 11:12. doi: 10.1186/1742-4933-11-12

92. Lozano T, Villanueva L, Durántez M, Gorraiz M, Ruiz M, Belsúe V, et al. Inhibition of FOXP3/NFAT Interaction Enhances T Cell Function after TCR Stimulation. J Immunol. (2015) 195:3180-9. doi: 10.4049/jimmunol.1402997

93. Karwot R, Übel C, Bopp T, Schmitt E, Finotto S. Increased immunosuppressive function of CD4(+)CD25(+)Foxp3(+)GITR+ $\mathrm{T}$ regulatory cells from $\operatorname{NFATc} 2((-/))$ mice controls allergeninduced experimental asthma. Immunobiology (2012) 217:905-11. doi: 10.1016/j.imbio.2012.01.004

94. Vaeth M, Bäuerlein CA, Pusch T, Findeis J, Chopra M, Mottok A, et al. Selective NFAT targeting in $\mathrm{T}$ cells ameliorates GvHD while maintaining antitumor activity. Proc Natl Acad Sci USA. (2015) 112:1125-30. doi: 10.1073/pnas. 1409290112

95. Yu D, Rao S, Tsai LM, Lee SK, He Y, Sutcliffe EL, et al. The transcriptional repressor Bcl-6 directs $\mathrm{T}$ follicular helper cell lineage commitment. Immunity (2009) 31:457-68. doi: 10.1016/j.immuni.2009. 07.002

96. Crotty S. Follicular helper CD4 T cells (TFH). Annu Rev Immunol. (2011) 29:621-63. doi: 10.1146/annurev-immunol-031210-101400

97. Fazilleau N, Mark L, McHeyzer-Williams LJ, McHeyzer-Williams MG. Follicular helper T cells: lineage and location. Immunity (2009) 30:324-35. doi: 10.1016/j.immuni.2009.03.003

98. Bollig N, Brüstle A, Kellner K, Ackermann W, Abass E, Raifer H, et al. Transcription factor IRF4 determines germinal center formation through follicular T-helper cell differentiation. Proc Natl Acad Sci USA. (2012) 109:8664-9. doi: 10.1073/pnas.1205834109

99. Betz BC, Jordan-Williams KL, Wang C, Kang SG, Liao J, Logan MR, et al. Batf coordinates multiple aspects of $\mathrm{B}$ and $\mathrm{T}$ cell function required for normal antibody responses. J Exp Med. (2010) 207:933-42. doi: $10.1084 /$ jem. 20091548
100. Ise W, Kohyama M, Schraml BU, Zhang T, Schwer B, Basu U, et al. The transcription factor BATF controls the global regulators of class-switch recombination in both B cells and T cells. Nat Immunol. (2011) 12:536-43. doi: 10.1038/ni.2037

101. Liu X, Chen X, Zhong B, Wang A, Wang X, Chu F, et al. Transcription factor achaete-scute homologue 2 initiates follicular T-helper-cell development. Nature (2014) 507:513-8. doi: 10.1038/nature12910

102. Choi YS, Gullicksrud JA, Xing S, Zeng Z, Shan Q, Li F, et al. LEF-1 and TCF-1 orchestrate $\mathrm{T}(\mathrm{FH})$ differentiation by regulating differentiation circuits upstream of the transcriptional repressor Bcl6. Nat Immunol. (2015) 16:980-90. doi: 10.1038/ni.3226

103. Ma CS, Avery DT, Chan A, Batten M, Bustamante J, Boisson-Dupuis $\mathrm{S}$, et al. Functional STAT3 deficiency compromises the generation of human $\mathrm{T}$ follicular helper cells. Blood (2012) 119:3997-4008. doi: 10.1182/blood-2011-11-392985

104. Vaeth M, Müller G, Stauss D, Dietz L, Klein-Hessling S, Serfling E, et al. Follicular regulatory $\mathrm{T}$ cells control humoral autoimmunity via NFAT2-regulated CXCR5 expression. J Exp Med. (2014) 211:545-61. doi: 10.1084/jem.20130604

105. Bhattacharyya S, Deb J, Patra AK, Thuy Pham DA, Chen W, Vaeth $\mathrm{M}$, et al. NFATc1 affects mouse splenic B cell function by controlling the calcineurin-NFAT signaling network. J Exp Med. (2011) 208:823-39. doi: 10.1084/jem.20100945

106. Yoshida H, Nishina $H$, Takimoto $H$, Marengère LE, Wakeham AC, Bouchard $\mathrm{D}$, et al. The transcription factor NF-ATc1 regulates lymphocyte proliferation and Th2 cytokine production. Immunity (1998) 8:115-24.

107. Oestreich KJ, Yoon $\mathrm{H}$, Ahmed R, Boss JM. NFATc1 regulates PD1 expression upon $\mathrm{T}$ cell activation. J Immunol. (2008) 181:4832-9. doi: 10.4049/jimmunol.181.7.4832

108. Kim HP, Korn LL, Gamero AM, Leonard WJ. Calcium-dependent activation of interleukin-21 gene expression in T cells. J Biol Chem. (2005) 280:25291-7. doi: 10.1074/jbc.M501459200

109. Jandl C, Liu SM, Cañete PF, Warren J, Hughes WE, Vogelzang A, et al. IL-21 restricts $\mathrm{T}$ follicular regulatory $\mathrm{T}$ cell proliferation through $\mathrm{Bcl}-6$ mediated inhibition of responsiveness to IL-2. Nat Commun (2017) 8:14647. doi: 10.1038/ncomms14647

110. Ray JP, Staron MM, Shyer JA, Ho PC, Marshall HD, Gray SM, et al. The Interleukin-2-mTORc1 kinase axis defines the signaling, differentiation, and metabolism of T helper 1 and Follicular B Helper T Cells. Immunity (2015) 43:690-702. doi: 10.1016/j.immuni.2015.08.017

111. Rasheed AU, Rahn HP, Sallusto F, Lipp M, Müller G. Follicular B helper $\mathrm{T}$ cell activity is confined to CXCR5(hi)ICOS(hi) CD4 T cells and is independent of CD57 expression. Eur J Immunol. (2006) 36:1892-903. doi: 10.1002/eji.200636136

112. Martinez GJ, Hu JK, Pereira RM, Crampton JS, Togher S, Bild N, et al. Cutting Edge: NFAT transcription factors promote the generation of follicular helper T cells in response to acute viral infection. J Immunol. (2016) 196:2015-9. doi: 10.4049/jimmunol.1501841

113. Woo SK, Kwon HM. Adaptation of kidney medulla to hypertonicity: role of the transcription factor TonEBP. Int Rev Cytol. (2002) 215:189-202. doi: 10.1016/S0074-7696(02)15009-1

114. Aramburu J, Drews-Elger K, Estrada-Gelonch A, Minguillón J, Morancho B, Santiago V, et al. Regulation of the hypertonic stress response and other cellular functions by the Rel-like transcription factor NFAT5. Biochem Pharmacol. (2006) 72:1597-604. doi: 10.1016/j.bcp.2006.07.002

115. Miyakawa H, Woo SK, Dahl SC, Handler JS, Kwon HM. Tonicity-responsive enhancer binding protein, a rel-like protein that stimulates transcription in response to hypertonicity. Proc Natl Acad Sci USA. (1999) 96:2538-42. doi: $10.1073 /$ pnas.96.5.2538

116. Ko BC, Turck CW, Lee KW, Yang Y, Chung SS. Purification, identification, and characterization of an osmotic response element binding protein. Biochem Biophys Res Commun. (2000) 270:52-61. doi: $10.1006 /$ bbrc. 2000.2376

117. Graef IA, Gastier JM, Francke U, Crabtree GR. Evolutionary relationships among Rel domains indicate functional diversification by recombination. Proc Natl Acad Sci USA. (2001) 98:5740-5. doi: 10.1073/pnas.1016 02398 
118. Burg MB, Kwon ED, Kültz D. Regulation of gene expression by hypertonicity. Annu Rev Physiol. (1997) 59:437-55.

119. Neuhofer W, Beck FX. Cell survival in the hostile environment of the renal medulla. Annu Rev Physiol. (2005) 67:531-55. doi: 10.1146/annurev.physiol.67.031103.154456

120. López-Rodríguez C, Aramburu J, Jin L, Rakeman AS, Michino M, Rao A. Bridging the NFAT and NF-kappaB families: NFAT5 dimerization regulates cytokine gene transcription in response to osmotic stress. Immunity (2001) 15:47-58. doi: 10.1016/S1074-7613(01)00165-0

121. Trama J, Go WY, Ho SN. The osmoprotective function of the NFAT5 Transcription Factor in T cell development and activation. J Immunol. (2002) 169:5477-5488. doi: 10.4049/jimmunol.169.10.5477

122. Berga-Bolaños R, Drews-Elger $\mathrm{K}$, Aramburu J, López-Rodríguez C. NFAT5 regulates $\mathrm{T}$ lymphocyte homeostasis and CD24-dependent $\mathrm{T}$ cell expansion under pathologic hypernatremia. J Immunol. (2010) 185:6624-35. doi: 10.4049/jimmunol.1001232

123. Berga-Bolaños R, Alberdi M, Buxadé M, Aramburu J, López-Rodríguez C. NFAT5 induction by the pre-T-cell receptor serves as a selective survival signal in T-lymphocyte development. Proc Natl Acad Sci USA. (2013) 110:16091-6. doi: 10.1073/pnas.1215934110

124. Luo T, Ji WJ, Yuan F, Guo ZZ, Li YX, Dong Y, et al. Th17/Treg Imbalance Induced by Dietary Salt Variation Indicates Inflammation of Target Organs in Humans. Sci Rep. (2016) 6:26767. doi: 10.1038/srep26767

125. Kleinewietfeld M, Manzel A, Titze J, Kvakan H, Yosef N, Linker RA, et al. Sodium chloride drives autoimmune disease by the induction of pathogenic TH17 cells. Nature (2013) 496:518-22. doi: 10.1038/nature11868

126. Alberdi M, Iglesias M, Tejedor S, Merino R, López-Rodríguez C, Aramburu J. Context-dependent regulation of Th17-associated genes and IFNgamma expression by the transcription factor NFAT5. Immunol Cell Biol. (2017) 95:56-67. doi: 10.1038/icb.2016.69

127. Xin Y, Cai H, Lu T, Zhang Y, Yang Y, Cui Y. miR-20b Inhibits T Cell Proliferation and activation via NFAT Signaling pathway in thymomaassociated Myasthenia Gravis. Biomed Res Int. (2016) 2016:9595718. doi: 10.1155/2016/9595718

128. Li W, Kong LB, Li JT, Guo ZY, Xue Q, Yang T, et al. MiR-568 inhibits the activation and function of $\mathrm{CD} 4(+) \mathrm{T}$ cells and Treg cells by targeting NFAT5. Int Immunol (2014) 26:269-81. doi: 10.1093/intimm/ dxt065

129. Kästle M, Bartel S, Geillinger-Kästle K, Irmler M, Beckers J, Ryffel B, et al. microRNA cluster 106a 363 is involved in T helper 17 cell differentiation. Immunology (2017) 152:402-13. doi: 10.1111/imm.12775

130. Boland BS, Widjaja CE, Banno A, Zhang B, Kim SH, Stoven S, et al. Immunodeficiency and autoimmune enterocolopathy linked to NFAT5 haploinsufficiency. J Immunol. (2015) 194:2551-60. doi: 10.4049/jimmunol.1401463

131. Abecassis M, Wong PY, Mason N, Cheung F, Mee AV, Cole EH, et al. Cyclosporin A metabolites suppress T-cell proliferation by concanavalin A and in a mixed lymphocyte reaction. Can J Surg. (1988) 31:145-50.

132. Szamel M, Bartels F, Resch K. Cyclosporin A inhibits T cell receptor-induced interleukin-2 synthesis of human T lymphocytes by selectively preventing a transmembrane signal transduction pathway leading to sustained activation of a protein kinase C isoenzyme, protein kinase C-beta. Eur J Immunol. (1993) 23:3072-81. doi: 10.1002/eji.1830231205

133. Umland SP, Shah H, Jakway JP, Shortall J, Razac S, Garlisi CG, et al. Effects of cyclosporin A and dinactin on T-cell proliferation, interleukin-5 production, and murine pulmonary inflammation. Am J Respir Cell Mol Biol. (1999) 20:481-92. doi: 10.1165/ajrcmb.20.3.3266

134. Almawi WY, Assi JW, Chudzik DM, Jaoude MM, Rieder MJ. Inhibition of cytokine production and cytokine-stimulated T-cell activation by FK506 (tacrolimus)1. Cell Transplant. (2001) 10:615-23. doi: $10.3727 / 000000001783986387$

135. Sakuma S, Higashi Y, Sato N, Sasakawa T, Sengoku T, Ohkubo Y, et al. Tacrolimus suppressed the production of cytokines involved in atopic dermatitis by direct stimulation of human PBMC system. (Comparison with steroids). Int Immunopharmacol. (2001) 1:1219-26. doi: 10.1016/S1567-5769(01)00059-5

136. Kogina K, Shoda H, Yamaguchi Y, Tsuno NH, Takahashi K, Fujio $\mathrm{K}$, et al. Tacrolimus differentially regulates the proliferation of conventional and regulatory CD4(+) T cells. Mol Cells (2009) 28:125-30. doi: 10.1007/s10059-009-0114-z

137. Aspeslet L, Freitag D, Trepanier D, Abel M, Naicker S, Kneteman N, Foster R. ISA(TX)247: a novel calcineurin inhibitor. Transplant Proc. (2001) 33:104851. doi: 10.1016/S0041-1345(00)02325-3

138. Grassberger M, Baumruker T, Enz A, Hiestand P, Hultsch T, Kalthoff F, et al. A novel anti-inflammatory drug, SDZ ASM 981, for the treatment of skin diseases: in vitro pharmacology. Br J Dermatol. (1999) 141:264-73. doi: $10.1046 / j .1365-2133.1999 .02974 . x$

139. Humar M, Pischke SE, Loop T, Hoetzel A, Schmidt R, Klaas C, et al. Barbiturates directly inhibit the calmodulin/calcineurin complex: a novel mechanism of inhibition of nuclear factor of activated T cells. Mol Pharmacol. (2004) 65:350-61. doi: 10.1124/mol.65.2.350

140. Wang H, Zhou CL, Lei H, Zhang SD, Zheng J, Wei Q. Kaempferol: a new immunosuppressant of calcineurin. IUBMB Life (2008) 60:549-54. doi: 10.1002/iub.94

141. Lei H, Qi Y, Jia ZG, Lin WL, Wei Q. Studies on the interactions of kaempferol to calcineurin by spectroscopic methods and docking. Biochim Biophys Acta (2009) 1794:1269-75. doi: 10.1016/j.bbapap.2009.04.014

142. Vega Lde L, Muñoz E, Calzado MA, Lieb K, Candelario-Jalil E, Gschaidmeir $\mathrm{H}$, et al. The 5-HT3 receptor antagonist tropisetron inhibits T cell activation by targeting the calcineurin pathway. Biochem Pharmacol. (2005) 70:369-80. doi: 10.1016/j.bcp.2005.04.031

143. Aramburu J, Garcia-Cózar F, Raghavan A, Okamura H, Rao A, Hogan PG. Selective inhibition of NFAT activation by a peptide spanning the calcineurin targeting site of NFAT. Mol Cell (1998) 1:627-37.

144. Aramburu J, Yaffe MB, López-Rodríguez C, Cantley LC, Hogan PG, Rao A. Affinity-driven peptide selection of an NFAT inhibitor more selective than cyclosporin A. Science (1999) 285:2129-33.

145. Noguchi H, Matsushita M, Okitsu T, Moriwaki A, Tomizawa K, Kang $\mathrm{S}$, et al. A new cell-permeable peptide allows successful allogeneic islet transplantation in mice. Nat Med. (2004) 10:305-9. doi: 10.1038/nm994

146. Martínez-Martínez S, Rodríguez A, López-Maderuelo MD, Ortega-Pérez I, Vázquez J, Redondo JM. Blockade of NFAT activation by the second calcineurin binding site. J Biol Chem. (2006) 281:6227-35. doi: 10.1074/jbc.M513885200

147. Li H, Pink MD, Murphy JG, Stein A, Dell'Acqua ML, Hogan PG. Balanced interactions of calcineurin with AKAP79 regulate Ca2+-calcineurin-NFAT signaling. Nat Struct Mol Biol. (2012) 19:337-45. doi: 10.1038/nsmb.2238

148. Sun L, Youn HD, Loh C, Stolow M, He W, Liu JO. Cabin 1, a negative regulator for calcineurin signaling in T lymphocytes. Immunity (1998) 8:703-11. doi: 10.1016/S1074-7613(00)80575-0

149. Isacoff WH, Bendetti JK, Barstis JJ, Jazieh AR, Macdonald JS, Philip PA. Phase II trial of infusional fluorouracil, leucovorin, mitomycin, and dipyridamole in locally advanced unresectable pancreatic adenocarcinoma: SWOG S(9700). J Clin Oncol. (2007) 25:1665-9. doi: 10.1200/JCO.2006.06.7637

150. Sieber M, Karanik M, Brandt C, Blex C, Podtschaske M, Erdmann F, et al. Inhibition of calcineurin-NFAT signaling by the pyrazolopyrimidine compound NCI3. Eur J Immunol. (2007) 37:2617-26. doi: 10.1002/eji.200737087

151. Jang JH, Iqbal T, Min KJ, Kim S, Park JW, Son EI, et al. Helenalininduced apoptosis is dependent on production of reactive oxygen species and independent of induction of endoplasmic reticulum stress in renal cell carcinoma. Toxicol In Vitro (2013) 27:588-96. doi: 10.1016/j.tiv.2012.10.014

152. Proksch P, Giaisi M, Treiber MK, Palfi K, Merling A, Spring H, et al. Rocaglamide derivatives are immunosuppressive phytochemicals that target NF-AT activity in T cells. J Immunol. (2005) 174:7075-84. doi: 10.4049/jimmunol.174.11.7075

153. Singh SK, Baumgart S, Singh G, König AO, Reutlinger K, Hofbauer LC, et al. Disruption of a nuclear NFATc2 protein stabilization loop confers breast and pancreatic cancer growth suppression by zoledronic acid. J Biol Chem. (2011) 286:28761-71. doi: 10.1074/jbc.M110.197533

154. Dai W, Wang F, He L, Lin C, Wu S, Chen P, et al. Genistein inhibits hepatocellular carcinoma cell migration by reversing the epithelialmesenchymal transition: partial mediation by the transcription factor NFAT1. Mol Carcinog. (2015) 54:301-11. doi: 10.1002/mc.22100

155. Román J, de Arriba AF, Barrón S, Michelena P, Giral M, Merlos $\mathrm{M}$, et al. UR-1505, a new salicylate, blocks $\mathrm{T}$ cell activation through 
nuclear factor of activated T cells. Mol Pharmacol. (2007) 72:269-79. doi: $10.1124 / \mathrm{mol} .107 .035212$

156. Sanderson JT, Clabault H, Patton C, Lassalle-Claux G, Jean-François $\mathrm{J}$, Paré AF, et al. Antiproliferative, antiandrogenic and cytotoxic effects of novel caffeic acid derivatives in LNCaP human androgendependent prostate cancer cells. Bioorg Med Chem. (2013) 21:7182-93. doi: 10.1016/j.bmc.2013.08.057

157. Aqil F, Munagala R, Vadhanam MV, Kausar H, Jeyabalan J, Schultz DJ, et al. Anti-proliferative activity and protection against oxidative DNA damage by punicalagin isolated from pomegranate husk. Food Res Int. (2012) 49:345-53. doi: 10.1016/j.foodres.2012.07.059

158. Choochuay K, Chunhacha P, Pongrakhananon V, Luechapudiporn R, Chanvorachote P. Imperatorin sensitizes anoikis and inhibits anchorageindependent growth of lung cancer cells. J Nat Med. (2013) 67:599-606. doi: 10.1007/s11418-012-0719-y

159. Baine Y, Stankunas BM, Miller P, Hobbs C, Tiberio L, Koch J, et al. Functional characterization of novel IL-2 transcriptional inhibitors. J Immunol. (1995) 154:3667-77.

160. Kuromitsu S, Fukunaga M, Lennard AC, Masuho Y, Nakada S. 3(13-Hydroxytridecyl)-1-[13-(3-pyridyl)tridecyl]pyridinium chloride (YM53792), a novel inhibitor of NF-AT activation. Biochem Pharmacol. (1997) 54:999-1005.

161. Caballero FJ, Navarrete CM, Hess S, Fiebich BL, Appendino G, Macho A, et al. The acetaminophen-derived bioactive $\mathrm{N}$-acylphenolamine AM404 inhibits NFAT by targeting nuclear regulatory events. Biochem Pharmacol. (2007) 73:1013-23. doi: 10.1016/j.bcp.2006.12.001

162. Yang QF, Dalgard CL, Eidelman O, Jozwik C, Pollard BS, Srivastava M, et al. Digitoxin induces apoptosis in cancer cells by inhibiting nuclear factor of activated T-cells-driven c-MYC expression. J Carcinog. (2013) 12:8. doi: 10.4103/1477-3163.112268

163. Ponticelli C, Tarantino A, Campise M, Montagnino G, Aroldi A, Passerini P. From cyclosporine to the future. Transplant Proc. (2004) $36(2$ Suppl.):557S-560S. doi: 10.1016/j.transproceed.2003.12.046

164. Azzi JR, Sayegh MH, Mallat SG. Calcineurin inhibitors: 40 years later, can't live without. J Immunol. (2013) 191:5785-91. doi: 10.4049/jimmunol.1390055

165. Borel JF. History of the discovery of cyclosporin and of its early pharmacological development. Wien Klin Wochenschr (2002) 114:433-7. doi: 10.1007/978-1-4615-9846-6_2

166. Borel JF, Feurer C, Gubler HU, Stähelin H. Biological effects of cyclosporin A: a new antilymphocytic agent. Agents Actions (1994) 3:179-86.

167. Goto T, Kino T, Hatanaka H, Nishiyama M, Okuhara M, Kohsaka M, et al. Discovery of FK-506, a novel immunosuppressant isolated from Streptomyces tsukubaensis. Transplant Proc. (1987) 5 (Suppl. 6):4-8.

168. Takahashi N, Hayano T, Suzuki M. Peptidyl-prolyl cis-trans isomerase is the cyclosporin A-binding protein cyclophilin. Nature (1989) 337:473-5.

169. Fischer G, Wittmann-Liebold B, Lang K, Kiefhaber T, Schmid FX. Cyclophilin and peptidyl-prolyl cis-trans isomerase are probably identical proteins. Nature (1989) 337:476-8.

170. Harding MW, Galat A, Uehling DE, Schreiber SL. A receptor for the immunosuppressant FK506 is a cis-trans peptidyl-prolyl isomerase. Nature (1989) 341:758-60.

171. Bram RJ, Hung DT, Martin PK, Schreiber SL, Crabtree GR. Identification of the immunophilins capable of mediating inhibition of signal transduction by cyclosporin A and FK506: roles of calcineurin binding and cellular location. Mol Cell Biol. (1993) 13:4760-9.

172. Alfaadhel T, Cattran D. Management of membranous nephropathy in western countries. Kidney Dis (2015) 1:126-37. doi: 10.1159/000437287

173. Yamaguchi M, Ando M, Yamamoto R, Akiyama S, Kato S, Katsuno $\mathrm{T}$, et al. Patient age and the prognosis of idiopathic membranous nephropathy. PLoS ONE (2014) 9:e110376. doi: 10.1371/journal.pone.0 110376

174. Zhang C, Zhang J, Yang B, Wu C. Cyclosporin A inhibits the production of IL-17 by memory Th17 cells from healthy individuals and patients with rheumatoid arthritis. Cytokine (2008) 42:345-52. doi: $10.1016 /$ j.cyto.2008.03.006
175. Wang K, Shi L, Yu Z, Deng Z, He A, Li S, et al. Cyclosporine A suppresses the activation of the Th17 cells in patients with primary sjogren's syndrome. Iran J Allergy Asthma Immunol. (2015) 14:198-207.

176. Naniwa T, Iwagaitsu S, Kajiura M. Efficacy of add-on tacrolimus on methotrexate to maintain clinical remission after rediscontinuation of a tumor necrosis factor inhibitor in rheumatoid arthritis patients who relapsed shortly after discontinuation of the same tumor necrosis factor inhibitor due to clinical remission. Mod Rheumatol. (2017) 27:29-34. doi: 10.3109/14397595.2016.1174394

177. Bechstein WO. Neurotoxicity of calcineurin inhibitors: impact and clinical management. Transpl Int (2000) 13:313-26. doi: 10.1111/j.1432-2277.2000.tb01004.x

178. Abramowicz D, Wissing KM, Broeders N. Nephrotoxicity of calcineurin inhibitors: new therapeutic approaches. Transplant Proc. (2000) 32(1A Suppl):3S-5S. doi: 10.1016/S0041-1345(00)00807-1

179. Snyder SH, Lai MM, Burnett PE. Immunophilins in the nervous system. Neuron (1998) 21:283-94.

180. Cameron AM, Steiner JP, Roskams AJ, Ali SM, Ronnett GV, Snyder SH. Calcineurin associated with the inositol 1,4,5-trisphosphate receptorFKBP12 complex modulates Ca2+ flux. Cell (1995) 83:463-72.

181. Chen SR, Hu YM, Chen H, Pan HL. Calcineurin inhibitor induces pain hypersensitivity by potentiating pre- and postsynaptic NMDA receptor activity in spinal cords. J Physiol. (2014) 592:215-27. doi: 10.1113/jphysiol.2013.263814

182. Martina M, Mozrzymas JW, Boddeke HW, Cherubini E. The calcineurin inhibitor cyclosporin A-cyclophilin A complex reduces desensitization of GABAA-mediated responses in acutely dissociated rat hippocampal neurons. Neurosci Lett. (1996) 215:95-8. doi: 10.1016/0304-3940(96)12957-8

183. Kumashiro S, Lu YF, Tomizawa K, Matsushita M, Wei FY, Matsui H. Regulation of synaptic vesicle recycling by calcineurin in different vesicle pools. Neurosci Res. (2005) 51:435-43. doi: 10.1016/j.neures.2004.12.018

184. Hens JJ, De Wit M, Ghijsen WE, Leenders AG, Boddeke HW, Kissmehl R, et al. Role of calcineurin in $\mathrm{Ca} 2+$-induced release of catecholamines and neuropeptides. J Neurochem. (1998) 71:1978-86. doi: $10.1046 / j .1471-4159.1998 .71051978 . x$

185. Hämäläinen M, Lahti A, Moilanen E. Calcineurin inhibitors, cyclosporin A and tacrolimus inhibit expression of inducible nitric oxide synthase in colon epithelial and macrophage cell lines. Eur J Pharmacol. (2002) 448:239-44. doi: 10.1016/S0014-2999(02)01947-7

186. Khanna AK, Cairns VR, Becker CG, Hosenpud JD. Transforming growth factor (TGF)-beta mimics and anti-TGF-beta antibody abrogates the in vivo effects of cyclosporine: demonstration of a direct role of TGF-beta in immunosuppression and nephrotoxicity of cyclosporine. Transplantation (1999) 67:882-9. doi: 10.1097/00007890-199903270-00016

187. Khanna A, Cairns V, Hosenpud JD. Tacrolimus induces increased expression of transforming growth factor-betal in mammalian lymphoid as well as nonlymphoid cells. Transplantation (1999) 67:614-9. doi: 10.1097/00007890-199902270-00021

188. Kakita T, Hasegawa K, Iwai-Kanai E, Adachi S, Morimoto T, Wada H, et al. Calcineurin pathway is required for endothelin-1-mediated protection against oxidant stress-induced apoptosis in cardiac myocytes. Circ Res. (2001) 88:1239-46. doi: 10.1161/hh1201.091794

189. Slowinski T, Subkowski T, Diehr P, Bachert D, Fritsche L, Neumayer $\mathrm{HH}$, et al. Interaction of the endothelin system and calcineurin inhibitors after kidney transplantation. Clin Sci. (2002) 103(Suppl. 48):396S-8S. doi: $10.1042 / C S 103 S 396 S$

190. Miroux C, Moralès O, Carpentier A, Dharancy S, Conti F, Boleslowski E, et al. Inhibitory effects of cyclosporine on human regulatory $\mathrm{T}$ cells in vitro. Transplant Proc. (2009) 41:3371-4. doi: 10.1016/j.transproceed.2009.08.043

191. Miroux C, Morales O, Ghazal K, Othman SB, de Launoit Y, Pancré V, et al. In vitro effects of cyclosporine $\mathrm{A}$ and tacrolimus on regulatory T-cell proliferation and function. Transplantation (2012) 94:123-31. doi: 10.1097/TP.0b013e3182590d8f

192. Choi JM, Sohn JH, Park TY, Park JW, Lee SK. Cell permeable NFAT inhibitory peptide Sim-2-VIVIT inhibits T-cell activation and alleviates allergic airway inflammation and hyper-responsiveness. Immunol Lett. (2012) 143:170-6. doi: 10.1016/j.imlet.2012.01.016 
193. Park S, Uesugi M, Verdine GL. A second calcineurin binding site on the NFAT regulatory domain. Proc Natl Acad Sci USA. (2000) 97:7130-5. doi: 10.1073/pnas.97.13.7130

194. Rodríguez A, Martínez-Martínez S, López-Maderuelo MD, Ortega-Pérez I, Redondo JM. The linker region joining the catalytic and the regulatory domains of CnA is essential for binding to NFAT. J Biol Chem. (2005) 280:9980-4. doi: 10.1074/jbc.C400401200

195. Adachi S, Amasaki Y, Miyatake S, Arai N, Iwata M. Successive expression and activation of NFAT family members during thymocyte differentiation. J Biol Chem. (2000) 275:14708-16. doi: 10.1074/jbc.275.19.14708

196. Lai MM, Burnett PE, Wolosker H, Blackshaw S, Snyder SH. Cain, a novel physiologic protein inhibitor of calcineurin. J Biol Chem. (1998) 273:1832531. doi: 10.1074/jbc.273.29.18325

197. Fuentes JJ, Genescà L, Kingsbury TJ, Cunningham KW, Pérez-Riba M, Estivill X, et al. DSCR1, overexpressed in Down syndrome, is an inhibitor of calcineurin-mediated signaling pathways. Hum Mol Genet. (2000) 9:168190. doi: $10.1093 / \mathrm{hmg} / 9.11 .1681$

198. Miskin JE, Abrams CC, Goatley LC, Dixon LK. A viral mechanism for inhibition of the cellular phosphatase calcineurin. Science (1998) 281:562-5. doi: $10.1126 /$ science.281.5376.562

199. Maksymowych WP, Jhangri GS, Aspeslet L, Abel MD, Trepanier DJ, Naicker S, et al. Amelioration of accelerated collagen induced arthritis by a novel calcineurin inhibitor, ISA(TX)247. J Rheumatol. (2002) 29:1646-52.

200. Naidoo P, Rambiritch V. Voclosporin (ISA247) for plaque psoriasis. Lancet (2008) 372:888-9; author reply: 889. doi: 10.1016/S0140-6736(08) 61391-4

201. Zanoni I, Ostuni R, Capuano G, Collini M, Caccia M, Ronchi AE, et al. CD14 regulates the dendritic cell life cycle after LPS exposure through NFAT activation. Nature (2009) 460:264-8. doi: 10.1038/nature08118

202. Goodridge HS, Simmons RM, Underhill DM. Dectin-1 stimulation by Candida albicans yeast or zymosan triggers NFAT activation in macrophages and dendritic cells. J Immunol. (2007) 178:3107-15. doi: 10.4049/jimmunol.178.5.3107
203. Jennings C, Kusler B, Jones PP. Calcineurin inactivation leads to decreased responsiveness to LPS in macrophages and dendritic cells and protects against LPS-induced toxicity in vivo. Innate Immun. (2009) 15:109-20. doi: $10.1177 / 1753425908100928$

204. Greenblatt MB, Aliprantis A, Hu B, Glimcher LH. Calcineurin regulates innate antifungal immunity in neutrophils. J Exp Med. (2010) 207:923-31. doi: 10.1084/jem.20092531

205. Buxadé M, Lunazzi G, Minguillón J, Iborra S, Berga-Bolaños R, Del Val $\mathrm{M}$, et al. Gene expression induced by Toll-like receptors in macrophages requires the transcription factor NFAT5. J Exp Med. (2012) 209:379-93. doi: 10.1084/jem.20111569

206. Klein M, Klein-Hessling S, Palmetshofer A, Serfling E, Tertilt C, Bopp T, et al. Specific and redundant roles for NFAT transcription factors in the expression of mast cell-derived cytokines. J Immunol. (2006) 177:6667-74. doi: 10.4049/jimmunol.177.10.6667

207. Baumruker T, Csonga R, Jaksche D, Novotny V, Prieschl EE. TNF-alpha and IL-5 gene induction in IgE plus antigen-stimulated mast cells require common and distinct signaling pathways. Int Arch Allergy Immunol. (1999) 118:108-11. doi: 10.1159/000024042

208. Lim S, Kim WJ, Kim YH, Lee S, Koo JH, Lee JA, et al. dNP2 is a blood-brain barrier-permeable peptide enabling ctCTLA-4 protein delivery to ameliorate experimental autoimmune encephalomyelitis. Nat Commun. (2015) 6:8244. doi: $10.1038 /$ ncomms 9244

Conflict of Interest Statement: The authors declare that the research was conducted in the absence of any commercial or financial relationships that could be construed as a potential conflict of interest.

Copyright (c) 2018 Lee, Kim and Choi. This is an open-access article distributed under the terms of the Creative Commons Attribution License (CC BY). The use, distribution or reproduction in other forums is permitted, provided the original author(s) and the copyright owner(s) are credited and that the original publication in this journal is cited, in accordance with accepted academic practice. No use, distribution or reproduction is permitted which does not comply with these terms. 